\title{
Impact of Outward Foreign Investment on Home Country Employment
}

\author{
Yao Yao \\ Hangzhou Institute of Service Engineering \\ Hangzhou Normal University \\ Hangzhou, China \\ yyaoexist@163.com
}

\begin{abstract}
Outward foreign direct investment has been growing fast in China over the past decade. Outward foreign direct investment influences home country employment through substitute effect and supplemental effect. This paper analyzed the mechanism of how outward foreign direct investment changes home country employment. The empirical studies examined the relation between China's outward foreign direct investment, with employment quality and quantity. The result indicates a positive relation exists between outward direct investment and employment, both in employment rate and average wages. As for comparison, this study also examined home country employment effect in Euro area. The empirical analysis suggests that there is no significant impact of outward foreign direct investment in home country employment in Euro area. As an emerging economy undergoing structural reform, employment quantity and quality in China benefit from outward foreign direct investments.
\end{abstract}

Keywords- outward foreign direct investments; employment; substitute effect; supplementary effect

\section{INTRODUCTION}

Outward foreign direct investment, originated from developing countries, has been growing fast all over the world over the past two decades. More and more multinational corporations from emerging economies have been investing and operating overseas. From the launch of "going out" strategy in 2002, outward foreign direct investment has been developed fast in China. In 2012, china has become the third largest source of foreign direct investment, right after the United States and Japan. Foreign direct investment from China has been spread all around the world, mainly in Asia and other developing economies, however in recent years investment in European and North American countries has seen rapid growth. Internationalization and structural reform in China has motivated Chinese companies to invest overseas, has been an important contribution to the world economy. In turn, the international investment has influences in the home country in many aspects. Outward foreign direct investment influences home country economy in macroeconomic growth, international trade, employment, industry structure, reverse technology spillovers and skill innovation. This paper concentrates on the employment effect of outward foreign direct investment, examines home country employment effect in China, and studies impact of outward direct investment in Euro area for comparison. The paper is structured as follows: firstly, analyze the positive effects and negative effects of outward foreign direct investments on home country employments; then analyze employment and outward direct investment in China; and then carry out empirical analysis between employment and outward foreign direct investment; finally give conclusions.

\section{EMPLOYMENT AND OUTWARD FOREIGN DIRECT INVESTMENT}

The employment effect of outward foreign direct investment is complicated. There is no consensus on the issue in academic community. Some research argue that outward foreign direct investment would hurt domestic employment, some indicate positive effect on home country employment, and others suggest that overseas direct investment has no significant influence on employment. The impact of outward foreign direct investment can be classified into two effects, namely supplementary effect and substitute effect. Combining the two types of effects, net employment effect can be obtained.

\section{A. Positive impact of outward foreign direct investment on home country employment}

Supplementary effect is the positive side of outward foreign direct investment on home country employment. Outward direct investment could gain access to foreign market, increase demand for domestic intermediate products, acquires natural resources, so as to improve domestic employment. Different motivations can have different effects in home country employment, some motivations, especially in the case of market-seeking and resource-acquisition driven outward direct investment, can help to improve home country employment situation. Market-seeking investment improves the demand side while resource-acquisition investment helps the supply side of macro economy, which in turn creates work opportunity in labor market. Investment in more developed countries, investments in higher valueadded industries, especially with advanced technology, has positive influence in macro economy, could provide more products and services in enlarging markets internationally. Expansion of multi-national corporations also requires more management level staff in the home country, provides not only more working opportunities, but also better positions. Parent company needs administrative personnel, legal professionals, financial department and management staff to manage its overseas business. Investments to higher income countries will not jeopardize home country employment, Blomström, Forsand and Lipsey's study suggest that Swedish companies mostly invested to higher income countries, and their outward direct investments helped the home country employments. In transitional economies, such 
as former Soviet Union eastern European countries, outward foreign direct investments improved their macro economic situation, pushed forward their international economic communications, hence provide more job opportunities (Navaretti, Castellani and Disdier, 2010). Outward foreign direct investment from smaller sized companies has more positive effect on employment than larger corporations.

\section{B. Negative impact of outward foreign direct investment on home country employment}

Substitute effect is the negative side of outward foreign direct investment on the home country employment. Outward direct investment could substitute domestic investment, which in turn reduced employment rate in the home country. One of the explanations for such negative effect is that higher cost domestic labor is substituted by lower cost overseas labor. One of the motivations for outward foreign direct investment is cost reduction. A typical mode of outward foreign direct investment is for more developed countries transfer their marginal industry to less developed countries with lower labor cost. Transfer manufacture sector to less developed countries can cause structural unemployment, which was experienced by many developed countries in the past several decades. Home country has seen loss of jobs in manufacturing sectors, in which workers has difficulties to find managerial jobs which is created by outward foreign direct investment. The studies on multi-national corporations in the United States indicate that outward foreign direct investment has negative effects on the home country employment. Especially, vertical investment of small companies in less developed countries has more significant negative effect on home country unemployment. Recently, some research argues that technological outward investment could also reduce job opportunity of domestic skilled labor force. Another explanation for negative effect is that more capital invested overseas means that less investment in the home country, which reduces labor demand. Outward direct investment reduced capital stock in the home country. However, in the long run, profit earned overseas may flow back to the home country and improve domestic investment. The other explanation is that outward foreign direct investment changed domestic employment through international trade. Intra corporation trade of multinational corporations facilitate import from affiliate overseas to parent company, hence reduced real output in the home country, and lowered employment rate.

\section{Outward foreign direct investment and employment in China}

From the launch of "going out" strategy, during the time period of 2003 to 2013, outward foreign direct investment from Chinese companies developed rapidly. China has become the third largest FDI source country in 2012. Outward foreign direct investment from Chinese corporations finds Asia and Latin America as first and second geographical destinations, mostly invested in developing countries. The investment geographical distribution is becoming more and more dispersed, with a growing trend in developed countries in Europe and North America, and a slightly decreasing trend in Asia. Outward foreign direct investment of Chinese companies has covered all industries. Leasing and business services, wholesale and retail trade, mining, manufacture and transportation are the most invested sectors. The degree of industry concentration of outward direct investment decreased over the past decade. From perspective of types of corporations participated in outward foreign direct investment, state-owned corporations are the dominate force. In top hundred outward foreign direct investors in China in 2013, only fourteen companies are from private sector. Top ten investors are mostly comprised of centralized large state-owned corporations. While more and more companies from private sector started their overseas strategy, the percentage of outward investment flow and stock form private companies has been growing over time. Companies from private sector seems to performance better in overseas investment, generate more revenue than state owned corporations. From the perspective of regional distribution of outward foreign direct investment in China, most investors are from East China, while companies form Central and West China participated more and more in outward investment. There are many contribution factors of employment situation in China. The employment rate and employment quality can be affected by outward foreign direct investment. Demographic bonus, which had support manufacturing goods exportation as an important driven factor of economy is gradually diminishing. Increasing labor cost, RMB appreciation, competition with other developing countries, all these factors lead to smaller profit margin in manufacturing sector. Companies are seeking overseas manufacturing as a cost effective solution, which indicate less job opportunities in domestic market. Technological and market seeking investment plays a more and more important role in China's outward foreign direct investment. Technology spillover and enlarging overseas market would improve employment situation, create more job opportunities with better quality. In the next sector, relation between outward foreign direct investments and employment in home country will be examined.

\section{EMPIRICAL STUDIES}

\section{A. Data description}

This paper examines impact of outward foreign direct investment on home country employment in China. Unemployment rates and employed staff number in China from 2004 to 2013 is selected as indicator of home country employment. Average wage is selected as indicator of quality of home country employment. The flows of outward foreign direct investment, import and export, are selected as explanatory variables, to examine how they influence home countryemployment. 
TABLE I. OUTWARD FOREIGN DIRECT INVESTMENT IN CHINA

\begin{tabular}{|c|c|c|c|}
\hline Year & Labor & OFDI flows & Wage \\
\hline 1999 & 4870.945 & 93.011 & $1,096.65$ \\
\hline 2000 & 5057.059 & 94.808 & $1,143.38$ \\
\hline 2001 & 3498.453 & 96.429 & $1,177.30$ \\
\hline 2002 & 1924.82 & 97.218 & $1,280.66$ \\
\hline 2003 & 2032.154 & 97.667 & $1,511.00$ \\
\hline 2004 & 2651.638 & 98.45 & $1,821.68$ \\
\hline 2005 & 4732.062 & 100 & $1,989.94$ \\
\hline 2006 & 5551.285 & 101.903 & $2,257.77$ \\
\hline 2007 & 8613.067 & 104.047 & $2,701.30$ \\
\hline 2008 & 7430.932 & 104.989 & $3,010.48$ \\
\hline 2009 & 3029.844 & 102.94 & $2,426.70$ \\
\hline 2010 & 4137.696 & 102.366 & $2,729.46$ \\
\hline 2011 & 4234.013 & 102.609 & $3,195.56$ \\
\hline 2012 & 1515.405 & 101.851 & 101.013 \\
\hline 2013 & 1876.443 & & 396.80 \\
\hline
\end{tabular}

TABLE II. OUTWARD FOREIGN DIRECT INVESTMENT IN EURO AREA

\begin{tabular}{|c|c|c|c|}
\hline Year & $\begin{array}{c}\text { OFDI flow } \\
\text { (US dollars, } \\
\text { billon) }\end{array}$ & $\begin{array}{c}\text { Employment } \\
\text { index }\end{array}$ & $\begin{array}{c}\text { Export } \\
\text { (US dollars, } \\
\text { billon) }\end{array}$ \\
\hline 1999 & 4870.945 & 93.011 & $1,096.65$ \\
\hline 2000 & 5057.059 & 94.808 & $1,143.38$ \\
\hline 2001 & 3498.453 & 96.429 & $1,177.30$ \\
\hline 2002 & 1924.82 & 97.218 & $1,280.66$ \\
\hline 2003 & 2032.154 & 97.667 & $1,511.00$ \\
\hline 2004 & 2651.638 & 98.45 & $1,821.68$ \\
\hline 2005 & 4732.062 & 100 & $1,989.94$ \\
\hline 2006 & 5551.285 & 101.903 & $2,257.77$ \\
\hline 2007 & 8613.067 & 104.047 & $2,701.30$ \\
\hline 2008 & 7430.932 & 104.989 & $3,010.48$ \\
\hline 2009 & 3029.844 & 102.94 & $2,426.70$ \\
\hline 2010 & 4137.696 & 102.366 & $2,729.46$ \\
\hline 2011 & 4234.013 & 102.609 & $3,195.56$ \\
\hline 2012 & 1515.405 & 101.851 & $3,198.61$ \\
\hline 2013 & 1876.443 & 101.013 & $3,396.80$ \\
\hline
\end{tabular}

For comparison, the employment effect in Euro area is also examined. The time period examined in this study start from the founding of Euro, in 1999, to 2013. Data of country group level is adopted, in this paper Euro area is examined as a whole.

The employment, wage, import and export data of China is from National Bureau of statistics. The outward foreign direct investment data of China is from Statistical bulletin of China's outward foreign direct investment. The employment index, wage, import and export data of Euro area is from IMF statistics. The outward foreign direct investment data of Euro area is from UNCAD statistics.

\section{B. Empirical studies onChina's home country employment effect}

In order to examine the relation between home country employment and outward foreign direct investment in China, the model is as follows:

$$
\begin{aligned}
& \ln L A B=c+\alpha_{1} \ln O F D I+\alpha_{2} \ln E X P O R T+e \\
& \ln W A G E=c+\beta_{1} \ln O F D I+\beta_{2} \ln E X P O R T+e
\end{aligned}
$$

Equation (1) examines the relation between employment quantity and outward foreign direct investment. Equation (2) examines the relation between employment quality and outward foreign direct investment. LAB indicates end of year employed staff number. OFDI indicates outward direct investment flow. EXPORT indicates net export of the year. WAGE indicates average wage level.

From estimation of the first equation, the function has good fitness, the R2 is 0.948281 , adjusted R2 is 0.935351 . Fstatistics indicate linear relation of the model. The variable LNOFDI passed t-statistics under 99\% confidential interval. A slightly positive relationship exists between outward foreign direct investment and employed staff number. The variable LNEXPORT does not pass t-statistics test, which indicate that no significant relation between net export and employment quantity. The estimation result is as follows:

$\ln L A B=11.007+0.021 \ln O F D I-0.006 \ln E X P O R T+e \quad \mathrm{~F}$ rom estimation of the second equation, the function has good fitness, the R2 is 0.972037, adjusted R2 is 0.965046. Fstatistics indicate linear relation of the model. The variable LNOFDI passed t-statistics under 99\% confidential interval. A slightly positive relationship exists between outward foreign direct investment and average wage. The variable LNEXPORT does not pass t-statistics test, which indicate that no significant relation between net export and employment quality. The estimation result is as follows: $\ln W A G E=4.378+0.489 \ln$ OFDI $-0.124 \ln E X P O R T+e$

The result shows that the two estimation equations both passed F-statistics, and the R-square indicate strong relationship. The OLS regression result suggests that outward foreign direct investment has a slightly positive impact on employment quantity as well as quality. The relation between net export and employed staff number or average wage is not significant, which means net export doesn't have direct impact on employment quantity nor quality. 


\section{C. Euro area \\ Empirical studies on OFDI and employment in}

To examine the relation between home country employment and outward foreign direct investment in the Euro area, the model is as follows:

$$
\ln E M P L O Y=c+\alpha_{1} \ln O F D I+\alpha_{2} \ln E X P O R T+e
$$

Equation (3) examines the relation between employment index and outward foreign direct investment. EMPLOY indicates employment index from IMF world economic outlook database. OFDI indicate annual outward foreign direct investment flow from the country group. EXPORT indicates export amount from the country group. The estimation result is as follows:

$\ln E M P L O Y=3.896+0.013 \ln O F D I+0.079 \ln E X P O R T+e$

From the estimation of equation (3), the function has good fitness, the $\mathrm{R}^{2}$ is 0.866749 , adjusted $\mathrm{R}^{2}$ is 0.844540 . Fstatistics indicate linear relation of the model. In the estimated equation, the coefficient of variable LNOFDI does not pass t-statistics test. The coefficient of variable LNEXPORT passed t-statistics under 99\% confidential interval, and has a positive coefficient. The result indicates that there is no significant impact of outward direct investment on employment. However, in the case of Euro area, export plays a positive role in promoting employment.

\section{CONCLUSIONS}

Outward foreign direct investment influences home country employment through two types of effect. Substitute effect and supplemental effect are negative and positive impact on home country employment. This paper analyzed the mechanism of how the two types of effect influence employment in home country. Then this paper examined the relation between China's outward foreign direct investment, with employment quality and quantity. The empirical analysis indicates that a positive relation exists between outward direct investment and employment. Both employment number and average wages respond positively to outward foreign direct investment. As for comparison, this study also examined home country employment effect in Euro area. The empirical analysis suggests that there is no significant impact of outward foreign direct investment in home country employment in Euro area, but a positive relation exists between export and employment. As an emerging economy undergoing structural reform, employment quantity and quality in China benefit from outward foreign direct investments.

\section{ACKNOWLEDGMENT}

This study is supported by the Natural Science Foundation of Zhejiang Province, Research on financial time series data mining, LQ15F020013.

\section{REFERENCES}

[1] J. Masso, U. Varblane and P. Vahter, "The Effect of Outward Foreign Direct Investment on Home-Country Employment in a LowCost Transition Economy”, Eastern European Economics, Vol. 46, Number 6 , Nov. 2008, pp. $25-59$.

[2] P. Debaere, H. Lee and J. Lee, "It matters where you go: Outward foreign direct investment and multinational employment growth at home”, Journal of Development Economics, Vol. 91, Issue 2, Mar. 2010, pp. 301-309.

[3] J. Konings and A.P. Murphy, "Do Multinational Enterprises Relocate Employment to Low-Wage Regions? Evidence from European Multinationals", Review of World Economics, Vol. 142, Issue 2, Jul. 2006, pp. 267-286.

[4] M. Blomström, G.. Fors and R.E. Lipsey, "Foreign Direct Investment and Employment: Home Country Experience in the United States and Sweden”, The Economic Journal, Vol. 107, Issue 445, Nov. 1997, pp. 1787-1797.

[5] G. B. Navaretti, D. Castellani and A. Disdier, "How does investing in cheap labour countries affect performance at home? Firm-level evidence from France and Italy”, Oxford Economic Papers, Vol. 62, Issue 2, 2010, pp.234-260.

[6] UNCAD. World Investment Report [R]. New York and Geneva: United Nations conference on trade and development, 2014

[7] IMF, World Economic Outlook Database [DB/OL]. http://www.imf.org/external/data.html

[8] UNCAD, Statistics, foreign direct investment, stocks and flows [DB/OL], http://unctadstat.unctad.org/wds/

[9] National bureau of statistics of the people's republic of china, Annual data, http://www.stats.gov.cn/

[10] P. Tsai and C. Tsay, "Outward foreign direct investment and inward international labor migration: substitutes or complements?", International Economic Journal, Vol. 22, No. 1, Mar. 2008, pp. 127139 